\title{
Genetic relatedness within the genus Campylobacter inferred from rpoB sequences
}

Correspondence
Peter Kuhnert
peter.kuhnert@vbi.unibe.ch

The genus Campylobacter was first proposed by M. Sebald and M. Véron in 1963 and included only the type species Campylobacter fetus and Campylobacter bubulus, now known as Campylobacter sputorum (Sebald \& Véron, 1963). These taxa had formerly been classified as Vibrio species. In 1973, M. Véron and R. Chatelain included several misclassified Vibrio in the distinct Campylobacter genus based on serological, biochemical and DNA-DNA hybridization investigations (On, 2001). Since then, the taxonomy of the genus has changed dramatically. At present, it comprises 17 species with validly published names and six recognized subspecies (On, 2001; Foster et al., 2004). In addition, strains belonging to C. sputorum are divided into three biovars, sputorum, fecalis and paraureolyticus, on the

Published online ahead of print on 23 December 2005 as DOI 10.1099/ijs.0.64109-0.

†Present address: MCL Medical Laboratories, CH-3186 Düdingen, Switzerland.

Abbreviation: MLST, multilocus sequence typing.

The GenBank/EMBL/DDBJ accession numbers for the 16S rRNA and $r p o B$ gene sequences of the Campylobacter species determined in this study are shown in Table 1.

Distance matrices for the 16S rRNA and rpoB gene sequences for all the strains investigated in this study are available as Supplementary Tables S1 and S2 in IJSEM Online. basis of their ability to produce catalase or urease (On et al., 1998; Vandamme \& On, 2001).

In general, members of the genus Campylobacter colonize the mucosal surfaces of the intestinal tract, oral cavity or urogenital tract of healthy, as well as diseased, humans and animals, especially birds. Several species may act as pathogens, causing disease in both human and animal hosts. Twelve of the 17 Campylobacter species are associated with human diseases. Campylobacter jejuni and Campylobacter coli are particularly frequent causative agents of human bacterial intestinal disorders worldwide (Skirrow, 1994). There have also been reported cases of diarrhoea in man caused by Campylobacter upsaliensis and Campylobacter lari, but the frequency of these infections is very low (Bourke et al., 1998; Van Doorn et al., 1998). Occasionally, Campylobacter species are implicated as causative agents of pericarditis, myocarditis and Guillain-Barré Syndrome (Kuwabara, 2004; Uzoigwe, 2005). The most important animal diseases are caused by Campylobacter fetus subsp. fetus, which is associated with abortion in cattle and sheep, and Campylobacter fetus subsp. venerealis, associated with infectious infertility in cattle (Skirrow, 1994).

Taxonomic classification and identification of Campylobacter species by phenotypic methods is often difficult and 
time-consuming because of their fastidious growth, low biochemical activity and the variability of results (Moore \& Madden, 2003). Therefore, several genotypic methods have been used for identification and taxonomic investigations within the genus Campylobacter (On, 1996). A large DNArRNA hybridization study on the Campylobacter complex was carried out by Vandamme et al. (1991) and provided a basis for the revision of its taxonomy. Numerical analysis of amplified fragment length polymorphism (AFLP) profiles has been used for the investigation of the genetic relationships within the genus Campylobacter (On \& Harrington, 2000). In other studies, $16 \mathrm{~S}$ rRNA and $23 \mathrm{~S}$ rRNA gene sequence-based phylogenies within the genus were analysed (Van Camp et al., 1993; Harrington \& On, 1999; Gorkiewicz et al., 2003). Kärenlampi et al. (2004) performed phylogenetic analysis within the genus Campylobacter using partial sequences of the heat shock protein gene groEL. Most recently, the genetic relatedness between C. jejuni and C. coli was investigated by multilocus sequence typing (MLST) of certain housekeeping genes (Dingle et al., 2005; Miller et al., 2005).

Analysis of the sequences of rRNA genes has deeply modified the taxonomy and identification of many groups of bacteria. However, this tool has limitations due to the low polymorphism of 16S rRNA gene sequence data and high intraspecies diversity in some cases (Harrington \& On, 1999; On, 2001). Therefore, additional genetic tools are needed to clarify the taxonomy of the genus Campylobacter and, at the same time, to enable the genetic identification of bacteria belonging to this genus. Analysis of the $r p o B$ gene encoding the beta-subunit of RNA polymerase has greatly supported the identification and the elaboration of genetic relationships in several groups of bacteria (Mollet et al., 1997; Kim et al., 2003; Korczak et al., 2004; Christensen et al., 2004; Drancourt et al., 2004). Recently, the rpoB gene has also been used to support the description of novel taxa (Angen et al., 2003; Kuhnert et al., 2004).

In this study, we used a universal amplification and sequencing approach for the $r p o B$ gene to investigate genetic relatedness within the genus Campylobacter.

Sequence comparison analysis was used to select the primers CamrpoB-L, 5' -CCAATTTATGGATCAAAC-3' , and RpoB-R, $5^{\prime}$-GTTGCATGTTNGNACCCAT-3', which enabled the amplification of a $524 \mathrm{bp}$ fragment from the rpoB gene of most Campylobacter species. The PCR product corresponded to region 1536-2059 bp of the Escherichia coli rpoB gene. For Campylobacter helveticus, Campylobacter curvus and Campylobacter lanienae, the primer CamrpoB-L1, 5'-GGKCARCTYTCKCAATTYATGG-3', was required. In this case, the gene fragment generated ( $535 \mathrm{bp}$ ) corresponded to the 1525-2059 bp position of the E. coli rpoB gene. The three primers could be combined in the same PCR at an annealing temperature of $54^{\circ} \mathrm{C}$ without interfering with each other. Amplification was carried out in $50 \mu$ l volumes containing $20 \mathrm{pmol}$ of each primer, $1 \mathrm{mM}$ dNTP, $1 \times$ reaction buffer B (supplied with FIREPol DNA polymerase),
$2.5 \mathrm{mM} \mathrm{MgCl} 2$ and $2.5 \mathrm{U}$ FIREPol polymerase (Solis BioDyne). Approximately $100 \mathrm{ng}$ template was added as genomic DNA or as lysate. Cycling conditions and purification steps were performed as previously described (Korczak et al., 2004). Finally, about $30 \mathrm{ng}$ purified PCR product was used for sequencing with the BigDye Terminator cycle sequencing kit (Applied Biosystems) using either CamrpoB-L, CamrpoB-L1 or RpoB-R as sequencing primers. Sequences were analysed on an ABI Prism 3100 Genetic Analyzer (Applied Biosystems) and then edited using SEQUENCHER software (GeneCodes). The three primers used for amplifying and sequencing the partial $r p o B$ gene of Campylobacter species were found to be universal within this genus, since all strains that have been analysed so far have yielded amplification products.

In order to confirm species identity and improve the available sequences (resolving unknown bases or generating longer sequence fragments), the $16 \mathrm{~S}$ rRNA gene sequence of all the Campylobacter species was determined in parallel according to a previously described method (Kuhnert et al., 2002). PCR and sequencing resulted in a $1 \cdot 3-1 \cdot 5 \mathrm{~kb}$ fragment, depending on the presence of an intervening sequence. All sequences obtained were deposited in databases for $16 \mathrm{~S}$ rRNA and $r p o B$ gene sequences using the SmartGene IDNS platform (www.idns-smartgene.com), which allows parallel sequence comparisons of both target genes. At the same time, all $r p o B$ sequences and improved $16 \mathrm{~S}$ rRNA gene sequences were deposited in GenBank. Campylobacter type strains and reference strains from bacterial culture collections were used in this study. For some species where only a few strains were available, some field strains were also included. These had been identified previously by the Swiss National Centre for Enteropathogenic Bacteria using standard phenotyping methods, and the original species designation was used in this study. The strains used in this study, their origin and the GenBank accession numbers of the corresponding $r p o B$ and $16 \mathrm{~S}$ rRNA gene sequences are given in Table 1. Distance matrices using Jukes-Cantor correction and phylogenetic analysis using neighbour-joining tree building were performed with the BioNumerics program version 4.0 (Applied Maths).

Congruence analysis in BioNumerics showed a good correlation between $r p o B$ and $16 \mathrm{~S}$ rRNA gene sequence-derived trees $(r=0 \cdot 81)$. Apart from a few incongruities, the trees showed a similar topology (Figs 1 and 2). Discrepancies in branching and clustering are most probably due to horizontal gene transfer, which is also known to occur with house-keeping genes such as 16S rRNA and rpoB (Ko et al., 2002; Acinas et al., 2004). The rpoB gene was found to provide a better resolution for Campylobacter species, with lower interspecies sequence similarities, ranging from $56 \cdot 4$ to $98.8 \%$, compared with those for the 16S rRNA gene (86-8-100\%). Thus, Campylobacter species can be better differentiated by using the $r p o B$ gene than the $16 \mathrm{~S}$ rRNA gene. This is also visible in Figs 1 and 2, which have the same scale bar, thereby showing clearly the higher resolution 
Table 1. Origin of strains and GenBank accession numbers of $16 \mathrm{~S}$ rRNA and rpoB gene sequences for the Campylobacter species used in this study

ATCC, American Type Culture Collection; CCUG, Culture Collection University of Goteborg; LMG, Bacteria Collection of the Belgian Coordinated Collections of Microorganisms; NCTC, National Collection of Type Cultures; Lio, Lior serogroup, NZ; E, Swiss National Centre for Enteropathogenic Bacteria; NA, not available.

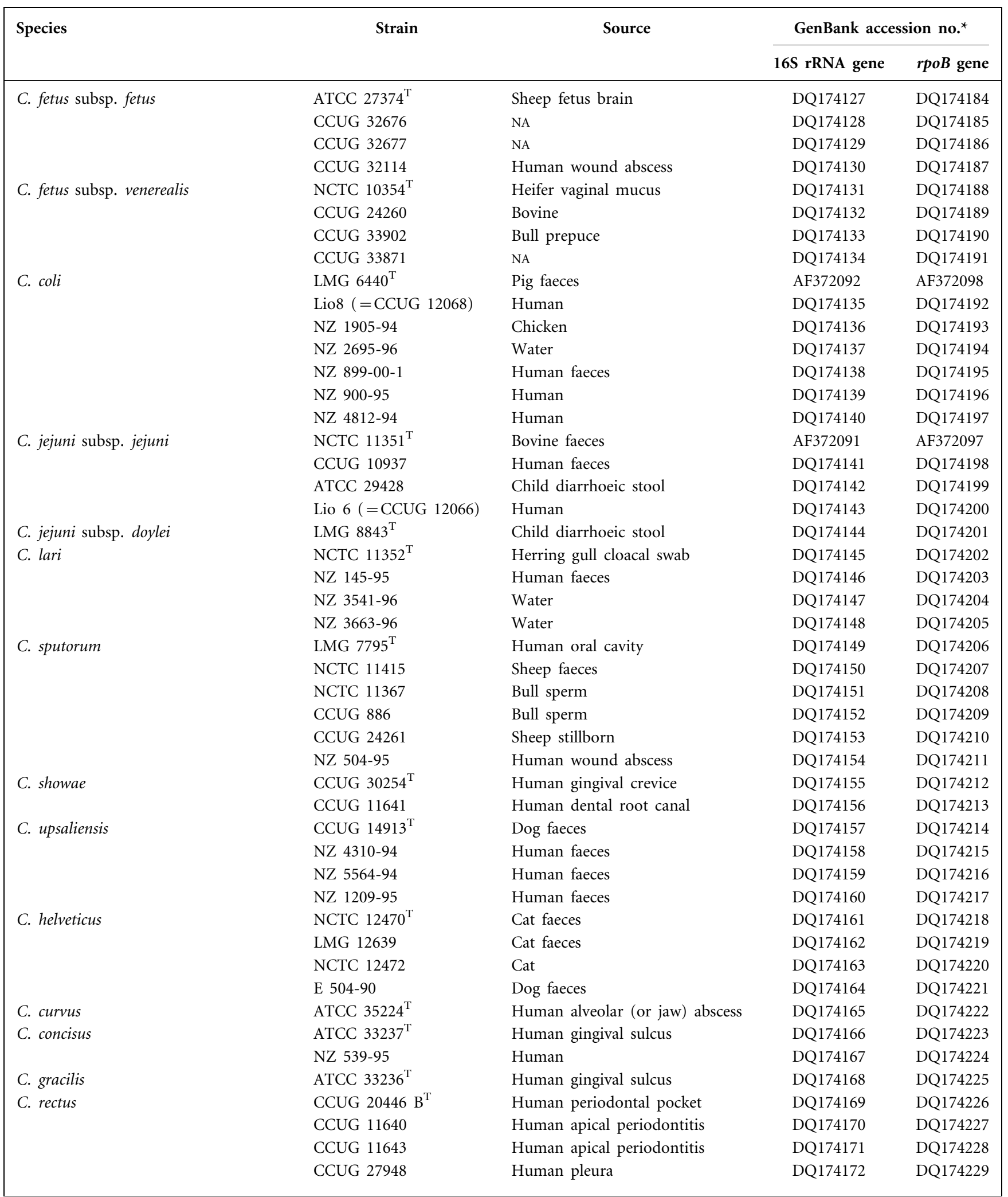


Table 1. cont.

\begin{tabular}{|c|c|c|c|c|}
\hline \multirow[t]{2}{*}{ Species } & \multirow[t]{2}{*}{ Strain } & \multirow[t]{2}{*}{ Source } & \multicolumn{2}{|c|}{ GenBank accession no.* } \\
\hline & & & 16S rRNA gene & rpoB gene \\
\hline \multirow{3}{*}{ C. mucosalis } & CCUG 10771 & Pig small intestine & DQ174174 & DQ174231 \\
\hline & CCUG 21559 & Pig necrotic colitis & DQ174175 & DQ174232 \\
\hline & CCUG 21560 & Pig necrotic colitis, colon & DQ174176 & DQ174233 \\
\hline \multirow{3}{*}{ C. hyointestinalis subsp. hyointestinalis } & NZ 701-94 & Calf faeces & DQ174178 & DQ174235 \\
\hline & NZ 3637-94 & Human faeces & DQ174179 & DQ174236 \\
\hline & NZ 5171-94 & Calf faeces & DQ174180 & DQ174237 \\
\hline C. hyointestinalis subsp. lawsonii & CCUG $34538^{\mathrm{T}}$ & Pig stomach & DQ195237 & DQ195238 \\
\hline C. lanienae & NCTC $13004^{\mathrm{T}}$ & Human & DQ174181 & DQ174238 \\
\hline C. hominis & NCTC $13146^{\mathrm{T}}$ & Human & DQ174182 & DQ174239 \\
\hline
\end{tabular}

*Sequences starting with DQ were all determined in this study.

obtained with $r p o B$ gene sequences. The distance matrices of the $16 \mathrm{~S}$ rRNA and $r p o B$ gene sequences for all the strains investigated in this study are available as Supplementary Tables S1 and S2 in IJSEM Online.

Differentiation between C. jejuni and C. coli, two genetically and phylogenetically closely related species, is difficult. Moreover, a few studies have shown that the hippurate hydrolysis test, which is critical for discrimination of these species, can sometimes give a false negative result for $C$. jejuni, leading to misidentification (Morris et al., 1985; Nicholson \& Patton, 1995). Many molecular tests that are useful for the differentiation of these two species have been developed, e.g. multiplex PCR or MLST (Cloak \& Fratamico, 2002; Dedieu et al., 2004; Dingle et al., 2005; Nayak et al., 2005; Miller et al., 2005). In this study, it was impossible to separate $C$. jejuni and C. coli strains based on the $16 \mathrm{~S}$ rRNA gene sequence (Fig. 1). Several C. jejuni and C. coli strains shared identical 16S rRNA gene sequences and nearly all the investigated strains of these taxa were mixed in a common cluster. Only the type strain of C. coli, LMG $6440^{\mathrm{T}}$, formed a separate branch (Fig. 1) as previously observed by Gorkiewicz et al. (2003). In contrast, the rpoB gene is strongly conserved within most $C$. coli strains, which shared $100 \%$ sequence identity with C. coli LMG $6440^{\mathrm{T}}$. The location of the C. coli type strain in the $r p o B$ tree on the same branch together with other $C$. coli strains is also seen with a tree based on groEL gene sequences (Kärenlampi et al., 2004). However, the still low $r p o B$ sequence divergence between $C$. coli and C. jejuni strains, ranging from only $1 \cdot 2 \%$ to $3 \cdot 8 \%$, makes it difficult to discriminate between the two species. A further discrepancy in the C. coli cluster in the 16S rRNA gene-based tree was found for strains NZ 2695-95 and NZ 1905-94, which formed a distinct cluster of their own in the rpoB-based tree (Fig. 2). Pairwise sequence comparison of these strains with C. coli LMG $6440^{\mathrm{T}}$ revealed $r p o B$ gene sequence similarities of only $83.6 \%$ and $82 \cdot 8 \%$, respectively. This suggests that strains NZ 2695-95 and NZ 1905-94 may be genetically atypical C. coli-like strains or represent a novel species distinct from $C$. coli. Between these two strains, the $r p o B$ sequence divergence was $6 \cdot 2 \%$, indicating further heterogeneity within putative $C$. coli-like strains. Further investigation of the relatedness of these two strains, including genotypic and phenotypic analysis, is necessary.

The type strain of C. lari, NCTC $11352^{\mathrm{T}}$, and the recently described novel species Campylobacter insulaenigrae displayed high $16 \mathrm{~S}$ rRNA gene sequence similarity and both species are located within the $C$. jejuni/C. coli cluster. In contrast, in the rpoB tree, $C$. lari and $C$. insulaenigrae are clearly separated from other members of the genus Campylobacter and are also clearly separated from each other. This clustering based on $r p o B$ sequences is supported by DNA-DNA hybridization results, which showed a close genetic relationship between $C$. insulaenigrae and $C$. lari and a significantly lower genetic relationship between $C$. insulaenigrae and $C$. jejuni (Foster et al., 2004).

It is known that $C$. lari is a phenotypically and genetically heterogeneous species. In a recent study by Duim et al. (2004), several groups were discerned within this species. A previous study based on numerical analysis of AFLP profiles demonstrated that classical urease-negative and ureasepositive strains form closely related, but distinct, clusters (On \& Harrington, 2000). Our results confirm that $C$. lari is a heterogeneous group as demonstrated in both the $r p o B$ and $16 \mathrm{~S}$ rRNA gene-derived trees. The $C$. lari cluster is split into two branches. The first branch is formed by the ureasenegative and nalidixic acid-resistant type strain NCTC $11352^{\mathrm{T}}$ and the clinical isolate NZ 145-95. The second branch includes the two urease-positive and nalidixic acidsensitive strains (NZ 3541-96 and NZ 3663-96) which share $100 \%$ sequence similarity within the $r p o B$ and $16 \mathrm{~S}$ rRNA 


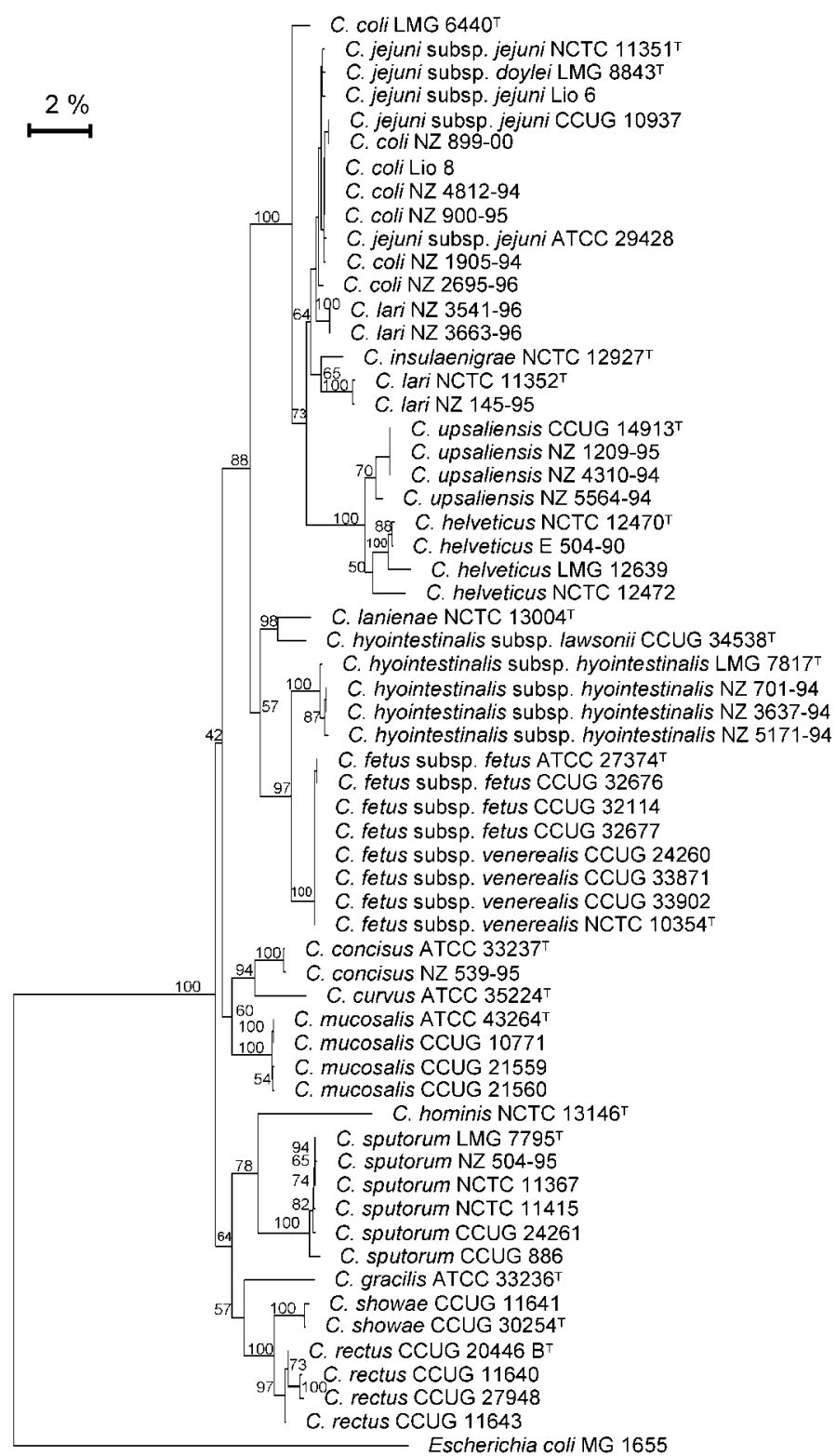

Fig. 1. Neighbour-joining phylogenetic tree of the genus Campylobacter based on 16S rRNA gene sequences. E. coli was used as an outgroup. Bootstrap values of 500 simulations are indicated at major branches. The GenBank accession numbers for the strains are shown in Table 1. Bar, $2 \%$ sequence divergence. gene fragments. Their high $r p o B$ sequence divergence from the type strain of $C$. lari $(11 \cdot 8 \%)$ once more confirms the genetic diversity of this species. Sequencing of the $r p o B$ gene therefore appears to be a promising tool for the differentiation of C. lari strains.

In both the $r p o B$ and $16 \mathrm{~S}$ rRNA gene-derived trees, $C$. upsaliensis and $C$. helveticus clustered in a similar way to that described for the phylogeny of the genus based on groEL gene sequences (Kärenlampi et al., 2004). A common cluster can be observed which consists of two clearly separated branches formed by C. upsaliensis and C. helveticus strains. It confirms their notable DNA similarity (Stanley et al., 1992). Moreover, C. helveticus appears to be a very genetically homogeneous group, reflected in a $100 \%$ sequence match in $r p o B$ genes between all investigated strains.
C. fetus and Campylobacter hyointestinalis subsp. hyointestinalis formed one cluster in both the $r p o B$ tree and the $16 \mathrm{~S}$ rRNA gene tree. The DNA-DNA hybridization study performed by Roop et al. (1984) also revealed some DNA similarity between these species. The two species are phenotypically and genotypically similar, but associated with different diseases (Skirrow, 1994; On, 2001). In the 16S rRNA gene sequence-based tree, $C$. hyointestinalis subsp. lawsonii clustered with $C$. lanienae and was clearly distinct from C. hyointestinalis subsp. hyointestinalis. Harrington et al. (1999) have already described wide $16 \mathrm{~S}$ rRNA gene sequence diversity $(1 \cdot 0-4 \cdot 3 \%)$ between members of the two C. hyointestinalis subspecies. In contrast, in the $r p o B$ gene based tree, both subspecies of $C$. hyointestinalis belong to the same subcluster, which is coupled to the branch formed by $C$. fetus strains. This location in the rpoB tree confirms the 


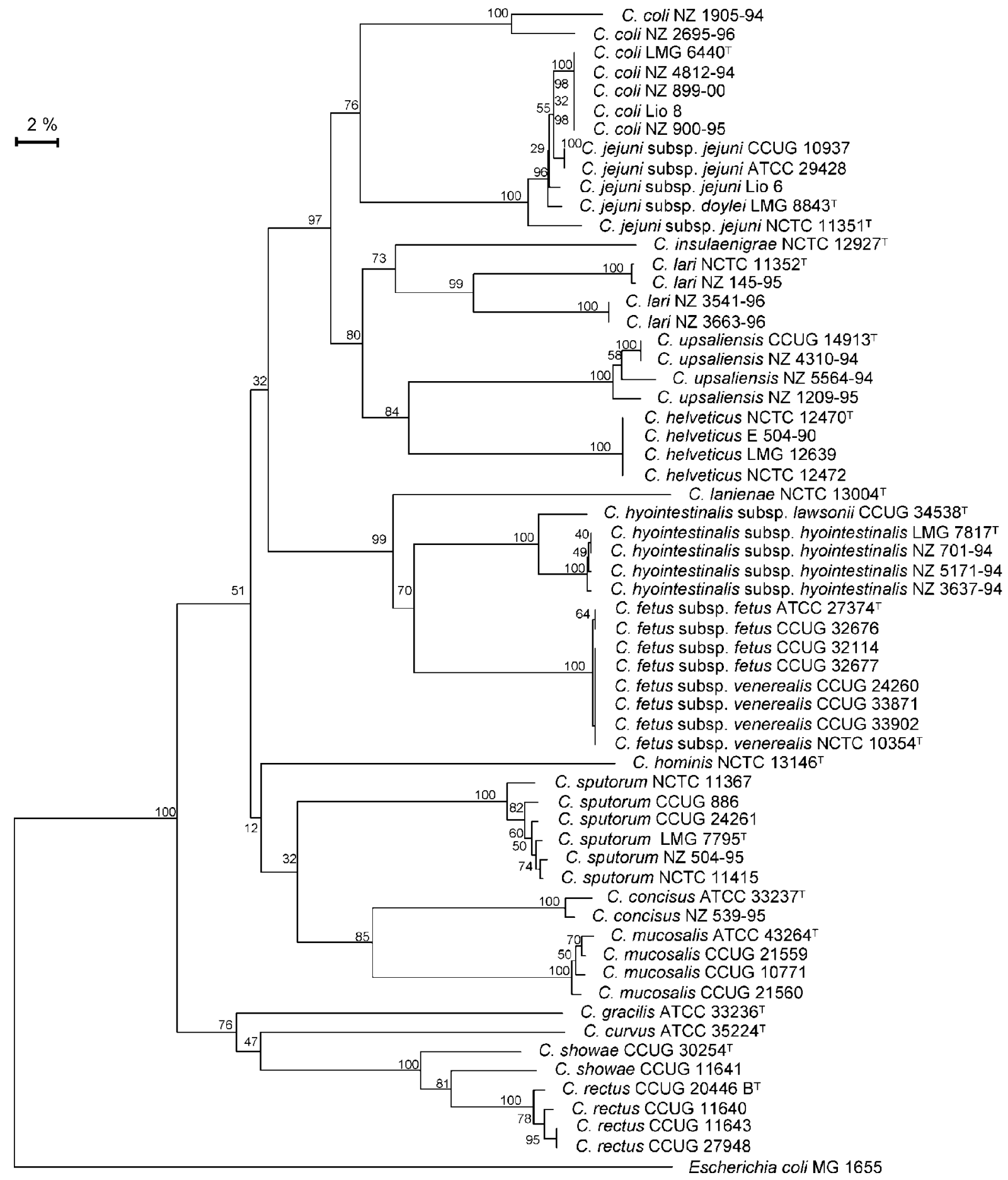

Fig. 2. Neighbour-joining phylogenetic tree of the genus Campylobacter based on partial rpoB gene sequences. E. coli was used as an outgroup. Bootstrap values of 500 simulations are indicated at major branches. The GenBank accession numbers for the strains are shown in Table 1 . Bar, $2 \%$ sequence divergence.

close phylogenetic relationship between these two subspecies and strongly supports the DNA-DNA hybridization results and phylogeny based on the groEL gene (On et al., 1995; Kärenlampi et al., 2004). In general, the rpoB and groEL genes possess similar characteristics concerning genetic relatedness within the genus Campylobacter. Both targets achieved nearly the same level of resolution of Campylobacter species. Moreover, a comparison of the tree topologies found with both gene targets shows similar clustering of species within the genus Campylobacter. However, the 
groEL gene tree is less extensive as it does not show all the recognized species and analyses fewer representative strains for the species that are included.

C. lanienae settles on a distinct branch, joined to the C. fetus/ C. hyointestinalis cluster, in both the $r p o B$ and $16 \mathrm{~S}$ rRNA gene trees.

Distinguishing between C. fetus subsp. fetus and C. fetus subsp. venerealis poses a special problem for veterinary laboratories. Although several phenotypic and genotypic methods are useful for discriminating these two subspecies (Hum et al., 1997; On \& Harrington, 2001), the final determination is based mainly on the different pathogenic associations of the subspecies. C. fetus subsp. fetus causes abortion in cattle and sheep, whereas C. fetus subsp. venerealis causes infectious infertility in cattle (Skirrow, 1994). Unfortunately, the resolution of the $r p o B$ gene, as is the case for the 16S rRNA gene, does not allow the differentiation of C. fetus subsp. fetus from C. fetus subsp. venerealis.

The species C. sputorum and Campylobacter hominis clustered together in the 16S rRNA gene-based tree, but formed two clearly distant branches. This topology is similar to that found for the $r p o B$ gene tree in this study, but is different from that shown in the 16S rRNA gene tree of the genus as described by Gorkiewicz et al. (2003).

In both the rpoB and $16 \mathrm{~S}$ rRNA gene-derived trees, Campylobacter mucosalis and Campylobacter concisus showed some genetic relationship, in agreement with DNA hybridization results (Roop et al., 1985).

In the $16 \mathrm{~S}$ rRNA gene tree, $C$. curvus clustered with $C$. concisus, whereas in the $r p o B$ gene tree $C$. curvus is on a separate branch close to Campylobacter showae, Campylobacter gracilis and Campylobacter rectus. All four species have been isolated from the gingival crevices of healthy individuals and patients with periodontal diseases. In the $16 \mathrm{~S}$ rRNA gene tree of Gorkiewicz et al. (2003), C. curvus showed the same phylogenetic position as observed in the $r p o B$ tree. The similar position and clustering of C. rectus and $C$. showae in both trees demonstrates a close phylogenetic relationship that has been observed previously (Gorkiewicz et al., 2003). However, the heterogeneity of the $r p o B$ sequences between the two $C$. showae strains is remarkable. The two strains showed a close relationship in their $16 \mathrm{~S}$ rRNA gene sequences, sharing $99 \cdot 8 \%$ sequence identity, but their $r p o B$ gene sequence similarity was only $92 \%$.

In certain Campylobacter species, intervening sequences (IVS) in the 16S rRNA gene have been described, particularly for C. sputorum, C. curvus, C. rectus, C. helveticus and C. hyointestinalis (Linton et al., 1994; Etoh et al., 1998). When compared with the 16S rRNA gene sequence of the type species C. fetus (GenBank accession no. DQ174127), all C. sputorum strains analysed in this study showed an IVS of 227-229 bp. In the C. curvus type strain, an IVS of $136 \mathrm{bp}$ was present. Two of the four $C$. rectus strains investigated, CCUG 11640 and CCUG 27948, contained an IVS of 189 bp when compared with the other two C. rectus strains.

In conclusion, the $r p o B$ gene has greater resolution than the $16 \mathrm{~S}$ rRNA gene sequence for the genus Campylobacter. The $r p o B$ resolution is sufficient for the differentiation of very closely related species as well as of most subspecies. However, it is probably not possible to separate C. coli and $C$. jejuni based on $r p o B$ gene sequences. A separate study including a large number of $C$. coli and $C$. jejuni strains could help to clarify whether the high $r p o B$ gene sequence conservation seen with C. coli strains might be useful for the differentiation of this species from $C$. jejuni. Generally, the $r p o B$ gene sequence better reflects DNA-DNA hybridization results than the 16S rRNA gene sequence, as previously observed for the family Pasteurellaceae (Korczak et al., 2004). Therefore, the $r p o B$ gene might be less prone to horizontal gene transfer and the partial $r p o B$ gene sequence of $530 \mathrm{bp}$ may better reflect the phylogeny of the genus Campylobacter (and eventually others) than does the 16S rRNA gene sequence. The $r p o B$ gene sequence might be particularly useful for diagnostic purposes when sequencing a short fragment could give a clear-cut result.

The universally applicable amplification and sequencing approach for partial $r p o B$ gene sequence determination that was devised in this study provides a powerful tool for DNA sequence-based identification of members of the genus Campylobacter.

\section{Acknowledgements}

This work was supported by a grant from the KTI (no. 6041.1 KTS). We thank G. Foster (Drummondhill, UK) for sending us the C. insulaenigrae type strain and Isabelle Brodard for technical help.

\section{References}

Acinas, S. G., Marcelino, L. A., Klepac-Ceraj, V. \& Polz, M. F. (2004). Divergence and redundancy of $16 \mathrm{~S}$ rRNA sequences in genomes with multiple rrn operons. J Bacteriol 186, 2629-2635.

Angen, O., Ahrens, P., Kuhnert, P., Christensen, H. \& Mutters, R. (2003). Proposal of Histophilus somni gen. nov., sp. nov. for the three species incertae sedis 'Haemophilus somnus', 'Haemophilus agni' and 'Histophilus ovis'. Int J Syst Evol Microbiol 53, 1449-1456.

Bourke, B., Chan, V. L. \& Sherman, P. (1998). Campylobacter upsaliensis: waiting in the wings. Clin Microbiol Rev 11, 440-449.

Christensen, H., Kuhnert, P., Olsen, J. E. \& Bisgaard, M. (2004). Comparative phylogenies of the housekeeping genes atpD, infB and $r p o B$ and the 16S rRNA gene within the Pasteurellaceae. Int J Syst Evol Microbiol 54, 1601-1609.

Cloak, O. M. \& Fratamico, P. M. (2002). A multiplex polymerase chain reaction for the differentiation of Campylobacter jejuni and Campylobacter coli from a swine processing facility and characterization of isolates by pulsed-field gel electrophoresis and antibiotic resistance profiles. J Food Prot 65, 266-273.

Dedieu, L., Pages, J. M. \& Bolla, J. M. (2004). Use of the omp50 gene for identification of Campylobacter species by PCR. J Clin Microbiol 42, 2301-2305. 
Dingle, K. E., Colles, F. M., Falush, D. \& Maiden, M. C. J. (2005). Sequence typing and comparison of population biology of Campylobacter coli and Campylobacter jejuni. J Clin Microbiol 43, 340-347.

Drancourt, M., Roux, V., Fournier, P. E. \& Raoult, D. (2004). rpoB gene sequence-based identification of aerobic Gram-positive cocci of the genera Streptococcus, Enterococcus, Gemella, Abiotrophia, and Granulicatella. J Clin Microbiol 42, 497-504.

Duim, B., Wagenaar, J. A., Dijkstra, J. R., Goris, J., Endtz, H. P. \& Vandamme, P. (2004). Identification of distinct Campylobacter lari genogroups by amplified fragment length polymorphism and protein electrophoretic profiles. Appl Environ Microbiol 70, 18-24.

Etoh, Y., Yamamoto, A. \& Goto, N. (1998). Intervening sequences in 16S rRNA genes of Campylobacter sp.: diversity of nucleotide sequences and uniformity of location. Microbiol Immunol 42, 241-243.

Foster, G., Holmes, B., Steigerwalt, A. G. \& 7 other authors (2004). Campylobacter insulaenigrae sp. nov., isolated from marine mammals. Int J Syst Evol Microbiol 54, 2369-2373.

Gorkiewicz, G., Feierl, G., Schober, C., Dieber, F., Kofer, J., Zechner, R. \& Zechner, E. L. (2003). Species-specific identification of campylobacters by partial 16S rRNA gene sequencing. J Clin Microbiol 41, 2537-2546.

Harrington, C. S. \& On, S. L. (1999). Extensive $16 \mathrm{~S}$ rRNA gene sequence diversity in Campylobacter hyointestinalis strains: taxonomic and applied implications. Int J Syst Bacteriol 49, 1171-1175.

Hum, S., Quinn, K., Brunner, J. \& On, S. L. (1997). Evaluation of a PCR assay for identification and differentiation of Campylobacter fetus subspecies. Aust Vet J 75, 827-831.

Kärenlampi, R. I., Tolvanen, T. P. \& Hanninen, M. L. (2004). Phylogenetic analysis and PCR-restriction fragment length polymorphism identification of Campylobacter species based on partial groEL gene sequences. J Clin Microbiol 42, 5731-5738.

Kim, K. S., Ko, K. S., Chang, M. W., Hahn, T. W., Hong, S. K. \& Kook, Y. H. (2003). Use of $r p o B$ sequences for phylogenetic study of Mycoplasma species. FEMS Microbiol Lett 226, 299-305.

Ko, K. S., Lee, H. K., Park, M. Y., Lee, K. H., Yun, Y. J., Woo, S. Y., Miyamoto, H. \& Kook, Y. H. (2002). Application of RNA polymerase beta-subunit gene $(r p o B)$ sequences for the molecular differentiation of Legionella species. J Clin Microbiol 40, 2653-2658.

Korczak, B., Christensen, H., Emler, S., Frey, J. \& Kuhnert, P. (2004). Phylogeny of the family Pasteurellaceae based on rpoB sequences. Int J Syst Evol Microbiol 54, 1393-1399.

Kuhnert, P., Frey, J., Lang, N. P. \& Mayfield, L. (2002). Phylogenetic analysis of Prevotella nigrescens, Prevotella intermedia and Porphyromonas gingivalis clinical strains reveals a clear species clustering. Int J Syst Evol Microbiol 52, 1391-1395.

Kuhnert, P., Korczak, B., Falsen, E., Straub, R., Hoops, A., Boerlin, P., Frey, J. \& Mutters, R. (2004). Nicoletella semolina gen. nov., sp. nov., a new member of Pasteurellaceae isolated from horses with airway disease. J Clin Microbiol 42, 5542-5548.

Kuwabara, S. (2004). Guillain-Barré syndrome: epidemiology, pathophysiology and management. Drugs 64, 597-610.

Linton, D., Dewhirst, F. E., Clewley, J. P., Owen, R. J., Burnens, A. P. \& Stanley, J. (1994). Two types of $16 \mathrm{~S}$ rRNA gene are found in Campylobacter helveticus: analysis, applications and characterization of the intervening sequence found in some strains. Microbiology 140, 847-855.

Miller, W. G., On, S. L. W., Wang, G., Fontanoz, S., Lastovica, A. J. \& Mandrell, R. E. (2005). Extended multilocus sequence typing system for Campylobacter coli, C. lari, C. upsaliensis, and C. helveticus. J Clin Microbiol 43, 2315-2329.

Mollet, C., Drancourt, M. \& Raoult, D. (1997). $r p o B$ sequence analysis as a novel basis for bacterial identification. Mol Microbiol 26, 1005-1011.
Moore, J. E. \& Madden, R. H. (2003). Comparison of eight phenotypic methods for subspecies characterization of thermophilic Campylobacter spp. isolated from pig liver. J Food Prot 66, 1079-1084.

Morris, G. K., el Sherbeeny, M. R., Patton, C. M., Kodaka, H., Lombard, G. L., Edmonds, P., Hollis, D. G. \& Brenner, D. J. (1985), Comparison of four hippurate hydrolysis methods for identification of thermophilic Campylobacter spp. J Clin Microbiol 22, 714-718.

Nayak, R., Stewart, T. M. \& Nawaz, M. S. (2005). PCR identification of Campylobacter coli and Campylobacter jejuni by partial sequencing of virulence genes. Mol Cell Probes 19, 187-193.

Nicholson, M. A. \& Patton, C. M. (1995). Evaluation of disk method for hippurate hydrolysis by Campylobacter species. J Clin Microbiol 33, 1341-1343.

On, S. L. (1996). Identification methods for campylobacters, helicobacters, and related organisms. Clin Microbiol Rev 9, 405-422.

On, S. L. (2001). Taxonomy of Campylobacter, Arcobacter, Helicobacter and related bacteria: current status, future prospects and immediate concerns. Symp Ser Soc Appl Microbiol 30, 1S-15S.

On, S. L. \& Harrington, C. S. (2000). Identification of taxonomic and epidemiological relationships among Campylobacter species by numerical analysis of AFLP profiles. FEMS Microbiol Lett 193 , $161-169$.

On, S. L. \& Harrington, C. S. (2001). Evaluation of numerical analysis of PFGE-DNA profiles for differentiating Campylobacter fetus subspecies by comparison with phenotypic, PCR and $16 \mathrm{~S}$ rDNA sequencing methods. J Appl Microbiol 90, 285-293.

On, S. L., Bloch, B., Holmes, B., Hoste, B. \& Vandamme, P. (1995). Campylobacter hyointestinalis subsp. lawsonii subsp. nov., isolated from the porcine stomach, and an emended description of Campylobacter hyointestinalis. Int J Syst Bacteriol 45, 767-774.

On, S. L., Atabay, H. I., Corry, J. E., Harrington, C. S. \& Vandamme, P. (1998). Emended description of Campylobacter sputorum and revision of its infrasubspecific (biovar) divisions, including $C$. sputorum biovar paraureolyticus, a urease-producing variant from cattle and humans. Int J Syst Bacteriol 48, 195-206.

Roop, R. M., Smibert, R. M., Johnson, J. L. \& Krieg, N. R. (1984), Differential characteristics of catalase-positive campylobacters correlated with DNA homology groups. Can J Microbiol 30, 938-951.

Roop, R. M., Smibert, R. M., Johnson, J. L. \& Krieg, N. R. (1985). DNA homology studies of the catalase-negative campylobacters and "Campylobacter fecalis", an emended description of Campylobacter sputorum, and proposal of the neotype strain of Campylobacter sputorum. Can J Microbiol 31, 823-831.

Sebald, M. \& Véron, M. (1963). Teneur en bases de l'ADN et classification des vibrions. Ann Inst Pasteur 105, 897-910 (in French).

Skirrow, M. B. (1994). Diseases due to Campylobacter, Helicobacter and related bacteria. J Comp Pathol 111, 113-149.

Stanley, J., Burnens, A. P., Linton, D., On, S. L., Costas, M. \& Owen, R. J. (1992). Campylobacter helveticus sp. nov. a new thermophilic species from domestic animals: characterization, and cloning of a species-specific DNA probe. J Gen Microbiol 138, 2293-2303.

Uzoigwe, C. (2005). Campylobacter infections of the pericardium and myocardium. Clin Microbiol Infect 11, 253-255.

Van Camp, G., Van De Peer, Y., Nicolai, S., Neefs, J. M., Vandamme, P. \& De Wachter, R. (1993). Structure of $16 \mathrm{~S}$ and $23 \mathrm{~S}$ ribosomal RNA genes in Campylobacter species - phylogenetic analysis of the genus Campylobacter and presence of internal transcribed spacers. Syst Appl Microbiol 16, 361-368.

Vandamme, P. \& On, S. L. (2001). Recommendations of the subcommittee on the taxonomy of Campylobacter and related bacteria. Int J Syst Evol Microbiol 51, 719-721. 
Vandamme, P., Falsen, E., Rossau, R., Hoste, B., Segers, P., Tytgat, R. \& De Ley, J. (1991). Revision of Campylobacter, Helicobacter, and Wolinella taxonomy: emendation of generic descriptions and proposal of Arcobacter gen. nov. Int J Syst Bacteriol 41, 88-103.
Van Doorn, L. J., Verschuuren-van Haperen, A., van Belkum, A., Endtz, H. P., Vliegenthart, J. S., Vandamme, P. \& Quint, W. G. V. (1998). Rapid identification of diverse Campylobacter lari strains isolated from mussels and oysters using a reverse hybridization line probe assay. J Appl Microbiol 84, 545-550. 